Vol. 3, No. 2, 2021

https://doi.org/10.23939/jtbp2021.02.024

Myron Hohol, Mykhaylo Kotiv, Ivan Peleshko, Dmytro Sydorak

\title{
REGULATION OF STRESS-DEFORMED STATE IN COMPRESSED ELEMENTS OF STEEL FRAMES
}

\author{
Lviv Polytechnic National University, \\ Department of Building Production, \\ gogolmyron@i.ua
}

(C) Hohol M., Kotiv M., Peleshko I., Sydorak D., 2021

The article is devoted to the regulation of the stress-strain state in the compressed elements of steel frames under full operating load. It is proposed to perform reinforcement of such elements with different end eccentricities of load application by rational regulation of the stress-strain state in the reinforcement elements. It is shown that the use of SDS adjustment for frame racks increases their bearing capacity and reduces deformability and welds. The new proposed technology of SDS regulation and possible constructive decisions are offered. Numerical experiment revealed high efficiency of application of the proposed solutions during the reconstruction and reinforcement of the metal frame system. The implementation of the proposed method of SDS regulation confirmed its effectiveness.

Keywords: reconstruction, racks, SDS regulation, reinforcement, stress-strain state, bearing capacity, racks with different eccentricities, experimental and numerical studies, implementation.

\section{Introduction}

Measures for the reconstruction of enterprises often lead to an increase in operational loads on the load-bearing structures of industrial buildings and structures in connection with the introduction of new equipment, improvement of technological processes, etc. The increase in operating loads, in turn, is the reason for the need to strengthen existing structures (Dinu et al., 2016; Lin et al., 2017).

Other reasons that necessitate the strengthening of structures are damage, arising during transportation, in the process of production of works and operation, and sometimes errors in the design and manufacture of structures (Bilsky et al., 2012; Vild et al., 2016).

The urgency of the work is due to the growing need for cost-effective and efficient ways to strengthen building structures under load.

Reinforcement of load-bearing structures (in particular, steel frames) can be carried out with their preliminary unloadingor under full operational load (Bilsky et al., 2012; DSTU, 2016). The latter in most cases is more cost-effective, as it eliminates or minimizes the costs associated with stopping production processes, dismantling equipment and reduces the time of repairs. Thus it is usually necessary to strengthen not all design as a whole, and only its separate elements, most intense or defective (Crawford, 2014).

\section{Analysis of basic research and publications}

Among the methods developed and used in practice to reinforce structural elements by increasing their cross-sectional area can be identified as follows,in which the use as reinforcement elements of unstressed (ordinary) rods and rods with initial prestresses. Reinforcement by unstressed elements is associated with significant disadvantages. The main ones are the need for partial unloading (from 20 to $40 \%$ ) of structures before their reinforcementand incomplete use of the strength of reinforcement element(DSTU, 2016; CEN, Eurocode 3, 2009). 
At strengthening of such designs by prestressed elements in turn the control over the forces created in them is necessary, ensuring the stability of the elements in the process of amplification, accounting for tension losses when they are included in the work, etc. The disadvantages of this method should also include the complexity of application as reinforcing elements of strip steel, the need to develop special, non-traditional for this method of amplification schemes, the need to introduce additional parts such as puffs, anchors, etc., which are not used in the further work of structures.

This probably explains the rare use of the latter method in the practice of amplification (Crawford, 2014).

\section{Presentation of the main research material}

Most of the disadvantages of the method of amplification of pre-stressed elements can be eliminated by rational redistribution (regulation) of the stress-deformed state (SDS) in reinforcement elements and reinforced construction rods (Gogol, 2018; Ghannam et al., 2016; Hohol et al., 2021).

The essence and feature of this method is that,that to the reinforced rod by means of any connections on one or from two parties unstressed elements of strengthening are connected,resting their ends either on the reinforced rod itself, or on adjacent load-bearing structures.Then by means of spacer devices (for example, mechanical or hydraulic jacks) in elements of strengthening the initial compressive force is created, resulting in the unloading of the reinforced rod. By changing the amount of compressive force in the reinforcement elements, you can achieve the following state, when the edge stresses in the reinforced rod and the gain elements near the plane of their contact are the same (Keykha et al., 2016; Gogol et al., 2018). Having provided further reliable communication of elements of strengthening with the strengthened rod the further work of such reinforced composite core can be considered as the only monolithic.

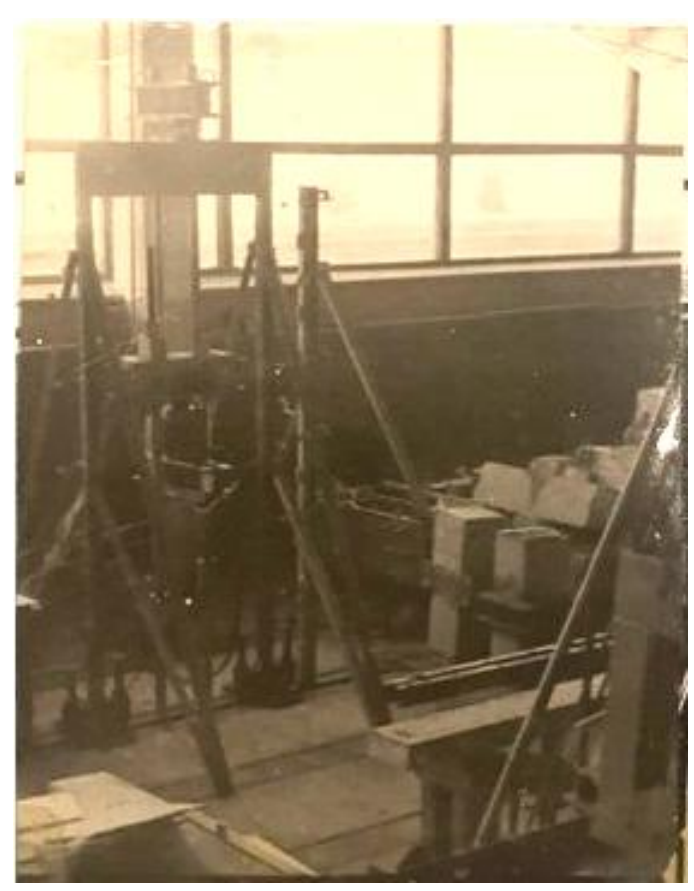

$a$

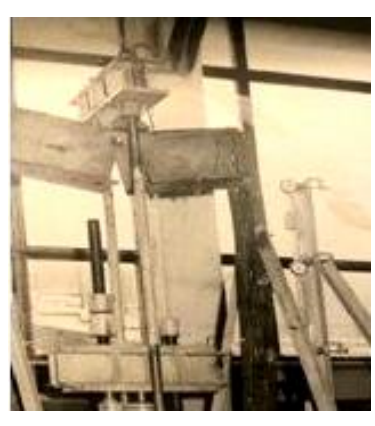

B

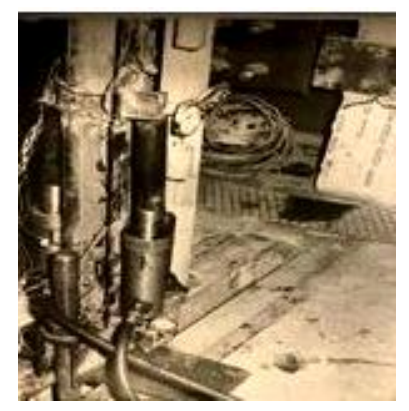

c

Fig. 1. a-general type of tests of frame racks with SDS adjustment in the process of strengthening under load; $b$-type of destruction after reinforcement and additional load; $c$ - regulation of the SDS in a rack by hydraulic jacks

The purpose of the study is to develop rational ways to strengthen the frame racks with tension elements, experimental, numerical and field verification of their effectiveness. To do this, you need to experimentally test and test the technology of strengthening the racks with different end eccentricities (Fig. 1). 
Tests in standard presses of compressed steel rods, loaded by longitudinal forces applied with finite eccentricities of different signs and significant magnitudes cause certain difficulties (Lin et al., 2021; Zhao et al., 2016; Xue et al., 2016). These difficulties are also connected with the fact that ane end of the rack (in the plane of reinforcement) there is a compression zone, and at the other - a tension zone. Therefore, tests of such cores were carried out not element by element in the press, and in pairs on a power floor as a part of a single-hinged frame (Fig. 1).

6 racks made of 2 angles $63 \times 5$ and connected in three frames with a height of $3.5 \mathrm{~m}$ and a run of $1.5 \mathrm{~m}$ were tested (Fig. 2). At the bottom of the rack was rigidly fastened with rods to the power floor.

At the top, each rack was rigidly connected to the frame crossbar, which consisted of two parts connected by a hinge in the middle (Fig. 2).

Loading of racks was carried out by means of a hydraulic jack through system of drafts, which were attached to the power floor in the middle of the length of the crossbar, ie at the location of the hinge. Thus artificially obtained two eccentrically compressed racks, loaded with longitudinal forces applied with different sign of the final eccentricities. The stability of the frame from the plane was provided by struts, which were hinged to the racks. The gain elements from the channel № 10 were tensioned with the help of hydraulic jacks (Fig. 2).
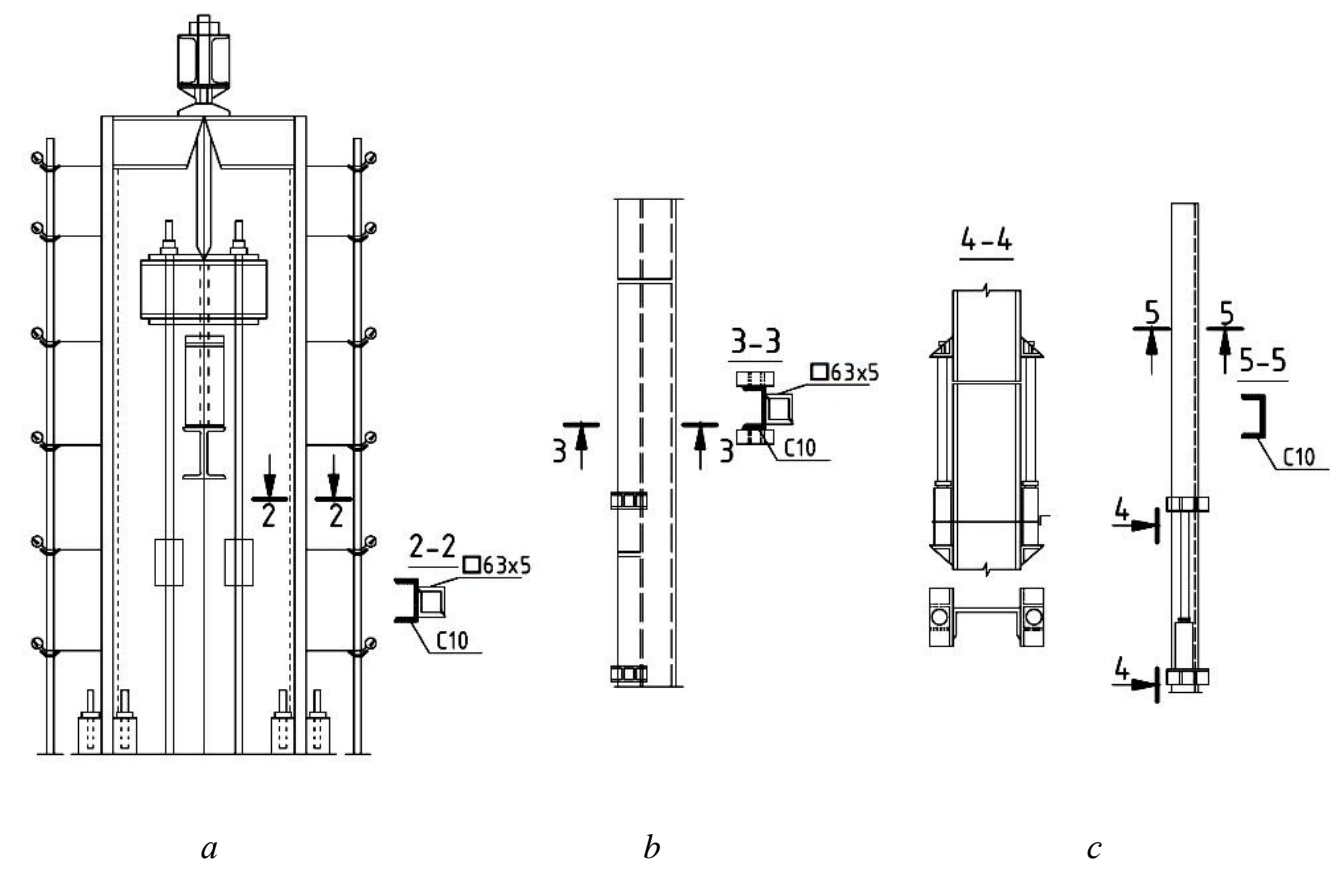

Fig. 2. The scheme of tests of frame racks with adjustment of the IBI in the course of strengthening under loading: a-the general scheme; $b$ - reinforced rack; $c$ - reinforcement element

Three single-hinged frames were tested. In the first, the reinforcement of the racks was performed with the adjustment of SDS mechanically using a 10-ton jack. In the second racks were reinforced without SDS adjustment, by simple welding of elements. In the third, monolithic racks were used in the frames, the cross-sectional area of which was similar to the total area of the main rod and the reinforcement element.

The procedure for amplification and the sequence of the SDS regulation process is similar to the above. After adjusting the SDS was performed by welding the key seams of the reinforcement element with the main rod with a step of 40 radii of inertia of the cross section of the reinforcement element. During the test, measurements of deflections were performed at 14 points of the frame struts, as well as deformations in the sections where these points were located. 
According to the test results, the deflections of the frame posts are constructed (Fig. 3), as well as moving the cross sections of the rack in the process of regulating SDS.

As can be seen from the graph, when reinforcing the racks with SDS adjustment, their deformability is less compared to the racks reinforced without SDS adjustment. Reduced (slightly) deformability of racks with SDS adjustment compared to monolithic can be explained by the influence of deflection, obtained by welding. The bearing capacity of the racks strengthened with adjustment of the SDS is less by $4 \%$ in comparison with monolithic racksand more by $18 \%$ compared to reinforced racks without adjustment.

Experiments have confirmed that the proposed method of SDS adjustment for frame racks allows not only to change the magnitude of the regulating force along the main rod, but also its sign. The use of SDS adjustment for frame rods increases their load-bearing capacity and reduces deformability and weld deformations. In general, tests of frame racks confirmed the possibility of reinforcement under full load, without prior unloadingand the ability to adjust the SDS in compressed elements with different end eccentricities of the load application.

To ensure rational design solutions for strengthening and reconstruction of complex many times statically indeterminate systems, appropriate methods have been developed to determine the parameters of SDS regulation, based on a combination of optimization methods and variant design. In this case, using an iterative algorithm to study the dependence of metal consumption on the number of pre-stressed excess connections determine the optimal distribution of forcesand additional metal with all possible amounts of pre-stressed excess connections.

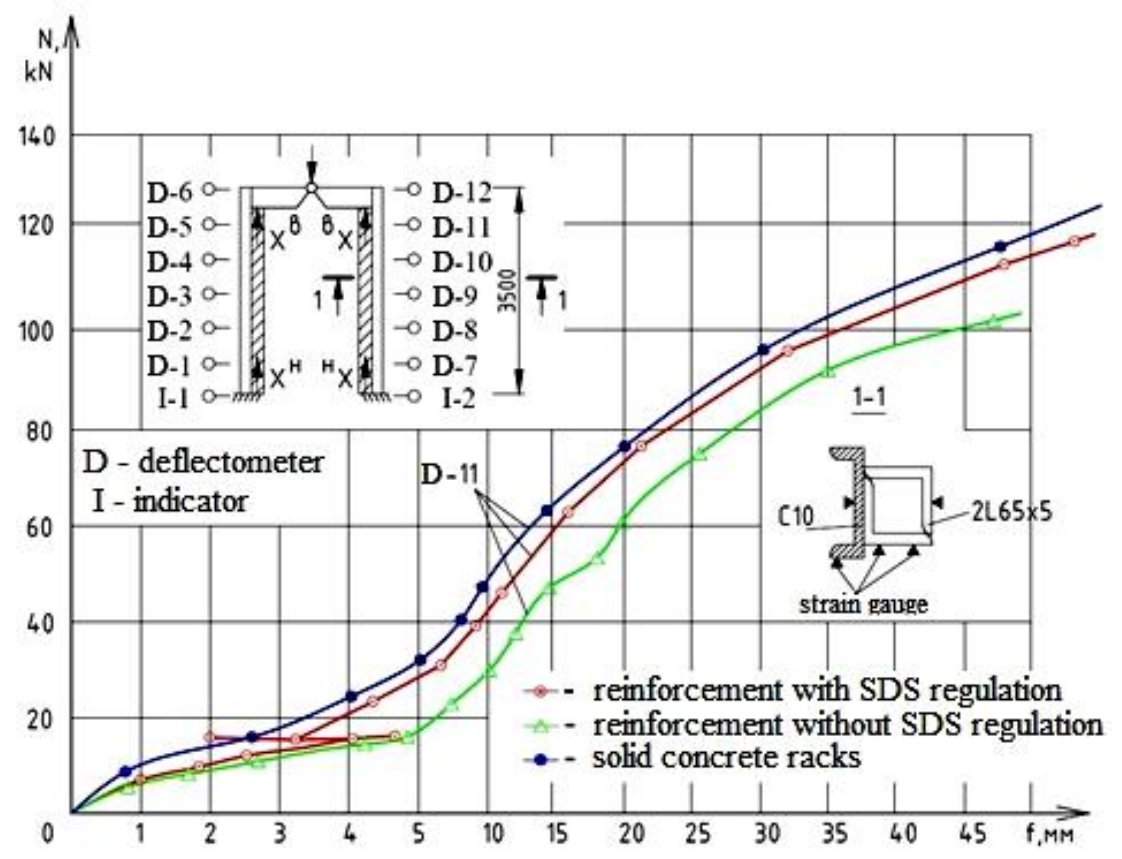

Fig. 3. Experimental graphs of deflections of frame racks reinforced under load

Then for each such distribution determine the cost of adjusting the effort in the extra ligaments and the cost "in fact" of the reinforcement elements. It is assumed that the smallest total value of these costs corresponds to a rational number of pre-stressed excess connections.

A numerical study of the effectiveness of the developed techniques during the design of the reconstruction and reinforcement of the operated multi-element metal intermediate frame of the main building of the chemical factory with degree of redundancy equal to 23 is executed. The need to strengthen the structures arose as a result of a promising change in the technological process. In order to identify the possibility of strengthening the frame only by adjusting the SDS in all the extra links, the problem of maximizing the bearing capacity of the frame (OptCAD program) was solved.

As a result of SDS regulation, the external load parameter increased from 0.75 to 0.918 , which, however, indicates the need to change the design scheme of the structure or strengthen the existing elements. 
Therefore, the minimum consumption of steel for frame reinforcement was determined by increasing the cross sections of existing elements. Analysis of the results showed that reducing the number of prestressed excess connections from 23 to 14 leads to a slight increase in the cost of additional metal (less than $1 \%$ ). The number of ties 14 corresponds to the maximum possible number of them, provided that the tensioning devices are placed only on the crossbars of the frame.

Tensioning devices can be installed on crossbars in places with insignificant bending moments, arising from the action of operating loads during SDS regulation. A study of the dependence of the minimum consumption of steel on the number of pre-stressed excess ties showed thatthat reducing the number of such connections from 14 to 8 has little effect on the consumption of steel when reinforcing the frame (see Fig. 4, $a$ ).

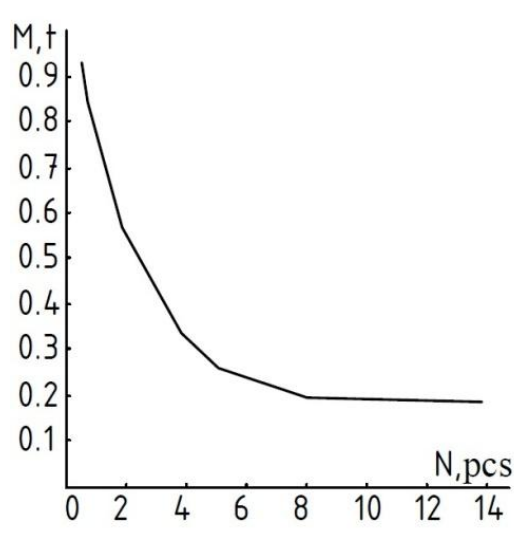

$a$

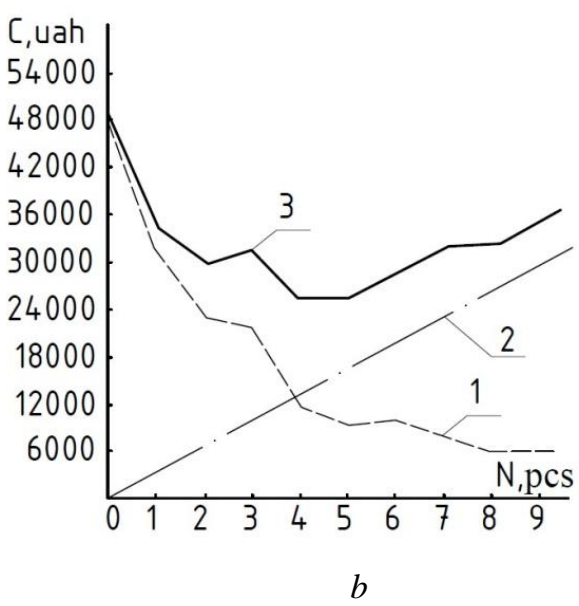

Fig. 4. Dependence on the number of $N$ pre-stressed excess connections: $a$ - the minimum consumption of steel to strengthen the frame; $b$ - the cost of "in fact":

1 -additional elements of reinforcement; 2 - regulation of SDS in redundant ties; 3 - the total cost "in fact" of structural reinforcement

For the practical implementation of SDS regulation in the extra ties of the frame developed removable tensioning devices, which differ in the maximum force perceived by the stops of the device. One of the tension devices is shown in Fig. 5.

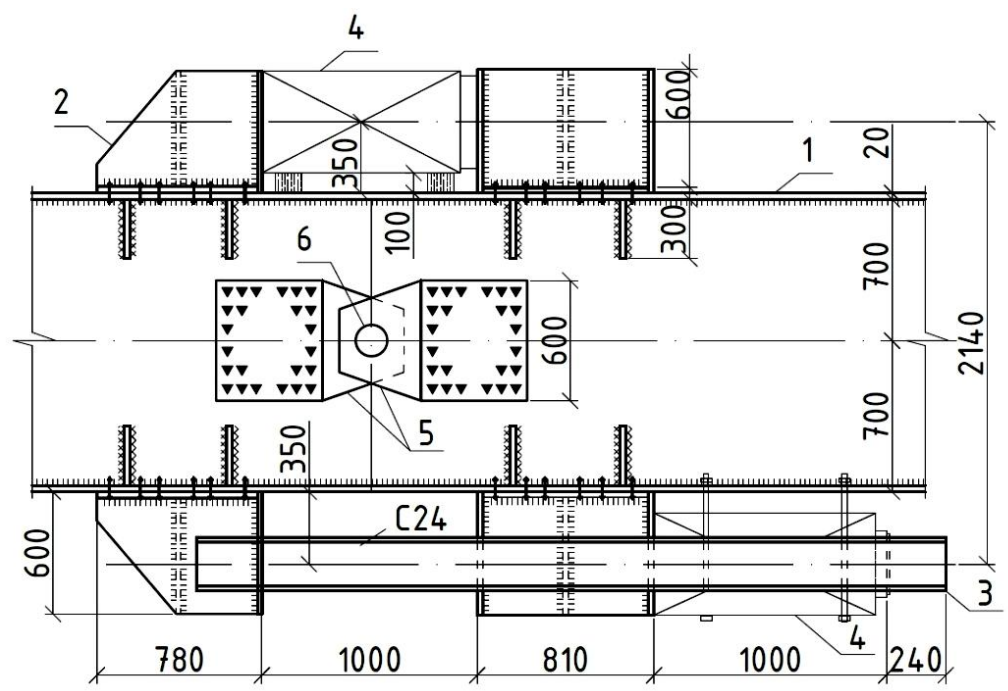

Fig. 5. The scheme of the mounted tensioning device: 1 - an I-beam element of the operated design; 2 -removable stops; 3 -traverse; 4-jacks;

5 - removable pads; 6 - hinged finger 
Taking into account the size of the Tension device and the technology of SDS regulation for the selected sequence of pre-stressed, the load-bearing capacity of a frame at all stages of existence of a design in the course of strengthening is checked. Application of the technique of optimal design of reconstruction and reinforcement of metal structures by the criterion of cost "in fact", based on a combination of the method of optimal and variant design, showed that the minimum cost "in fact" is achieved by adjusting the effort in 4-5 extra connections (Fig. $4, b$ ).

In this case, the cost "in fact" is reduced by half, and the cost of metal reinforcement by 3.3 times.

The efficiency of reinforcement with SDS regulation was also confirmed during the reinforcement of the load-bearing structures of PJSC "Podilsky Cement" in the city of Kamyanets-Podilsky LLC "Balko".

In 2013, in the process of inspection of the supporting structures of the telpher of the construction of a raw material mill with a capacity of 165 tons was found, that the supporting load-bearing struts made of pipes on which beams with monorails of the telpher movement are installed have received significant lateral deflections (bends) in the horizontal plane.

The reason for such deflections were inaccuracies in the installation of structures and significantly inflated flexibility of the racks themselves, about 150 . These racks were reinforced by reducing their free length in one plane and increasing the rigidity of the rack in another plane, increasing their cross section by installing two additional elements of pipes with a diameter of $102 \mathrm{~mm}$ (Fig. 6).

To reduce deflection and stresses in the supporting beams and deflections of the racks themselves, in the process of amplification were created regulatory efforts in additional - amplifying elements: - $80 \mathrm{kN}$ in the element set on the eccentric side of the force and $10 \mathrm{kN}$ in the element on the opposite side. Adjustment was carried out by the initial bending of the reinforcing elements and tightening them to the design position with horizontal rods. In the design position, after strengthening the rack received a cross section of considerable rigidity (Fig. 6). Reinforcement work was performed in the same year and currently the structures are in operation and are in normal condition.

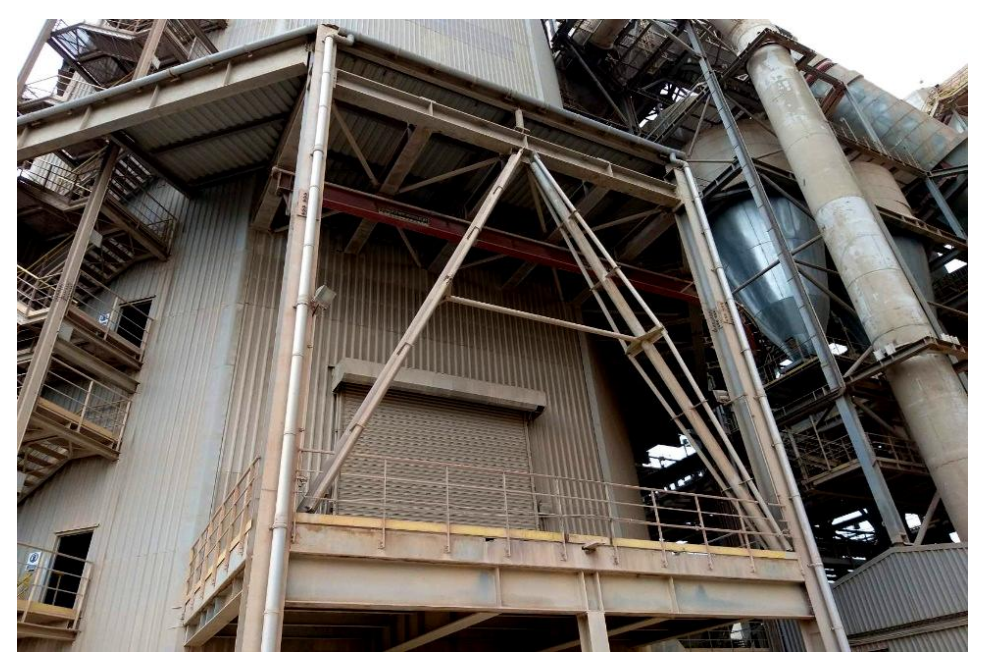

Fig. 6. General view of structures after reinforcement under load

\section{Conclusions}

A new method of SDS regulation in compressed elements with different finite eccentricities of load application is proposed.

It has been experimentally confirmed that hat the proposed method of SDS adjustment for frame racks allows not only to change the magnitude of the regulating force along the main rod, but also its sign.

The use of SDS adjustment for frame racks increases their load-bearing capacity and reduces deformability and welds. 
The technology of SDS regulation and possible constructive decisions of removable tensioning devices for introduction of bending moments in superfluous ligaments of frame systems are offered.

A method for selecting rational prestressed excess connections in many times statically indeterminate structures has been developed, based on a combination of optimal and variant design methods.

High efficiency of application of the offered decisions for designing of reconstruction and strengthening of the considered metal frame system with a high degree of static uncertainty is revealed. In this case, the cost "in fact" is reduced by half, and the cost of metal reinforcement - 3.3 times.

The implementation of the proposed method of SDS regulation when strengthening the frame racks confirmed its effectiveness.

\section{References}

Bilsky, M. R., Kinash, R. I. (2012). Calculation of force regulation in the process of reinforcement of compressed elements of steel frames. Theory and practice of construction. Bulletin of the National University "Lviv Polytechnic” № 737, 5-14 p. (in Ukrainian). http://ena.lp.edu.ua:8080/xmlui/bitstream/handle/ntb/16510/2-Bilsky5-14.pdf

Crawford, J. E. (2014).Retrofit Methods to Mitigate Progressive Collapse. 55 p. https://www.engr.psu.edu.

Martin Vild, Miroslav Bajer. (2016). Strengthening of Steel Columns under Load: Torsional-Flexural Buckling. Advances in Building Technologies and Construction Materials 2016. Volume 2016. https://doi.org/ $10.1155 / 2016 / 2765821$

Mohamed Ghannam, Nabil S. Mahmoud, Ahmed Badr, Fikry A. Salem. (2016). Effect of post tensioning on strengthening different types of steel frames. Journal of King Saud University - Engineering Sciences. Volume 29, Issue 4, October 2017, Pages 329-338 https://doi.org/10.1016/j.jksues.2016.07.001

Hohol M. V. (2018). Tension regulation in steel combined structures [monograph]. Kyiv: Stal, 222 p (in Ukrainian). https://bit.ly/3FBL971

Gogol, M., Zygun, A., Maksiuta, N. (2018). New effective combined steel structures. International Journal of Engineering and Technology. (Vol 7, pp. 343-348). DOI:https://doi.org/10.14419/ijet.v7i3.2.14432

Gogol Miron. (2015).The combined metal structures of the estimated regulation efforts. Czasopismo inżynierii lądowej, środowiska i architektury. Journal of civil engineering, environment and architecture, JCEEA. Rzeszow, Poland. Rzeszow University of Technology, 2015. - vol. 62 (4/15). - pp. 107-118. DOI: 10.7862/rb.2015.181

Myron Hohol, Ivan Peleshko, Oleksii Petrenko, Dmytro Sydorak. (2021). Analysis of calculation regulation methods in steel combined trusses. Theory and Building Practice. Vol. 3, No. 1: 64-71.DOI: https://doi.org/ 10.23939/jtbp2021.01.064

DSTU B B.3.1-2: 2016. Repair and reinforcement of load-bearing and enclosing building structures and foundations of buildings and structures (in Ukrainian). http://online.budstandart.com/ua/catalog/doc-page.html? id_doc $=66126$

CEN, "Eurocode 3: design of steel structures-part 1-1: general rules and rules for buildings", EN 1993-11:2005, 2009. https://www.phd.eng.br/wp-content/uploads/2015/12/en.1993.1.1.2005.pdf

Amir Hamzeh Keykha, Masoud Nekooei, Reza Rahgozar. (2016).Analysis and strengthening of SHS steel columns using CFRP composite materials. Composites: Mechanics 7(4):275-290. DOI:10.1615/CompMechComput ApplIntJ.v7.i4.20

Weiwei Lin, Nozomu Taniguchi, Teruhiko Yoda. (2017). A preventive strengthening method for steel columns: Experimental study and numerical analyses.Journal of Constructional Steel Research, Volume 138, Pages 357-368. https://doi.org/10.1016/j.jcsr.2017.07.019

Hui Lin, Ying Hu, Song-Ting Qian, Maher Sulaiman, (2021). Application of Continuous Strength Method in high strength steel sections.Special Issue: EUROSTEEL 2021 Sheffield - Steel's coming home.Volume 4, Issue 2-4. P.1612-1616. https://doi.org/10.1002/cepa.1463

Jianyang Xue, Liangjie Qi. (2016). Experimental studies on steel frame structures of traditional-style buildings.Steel and Composite Structures 22(2):235-255. DOI:10.12989/scs.2016.22.2.235

Florea Dinu, Ioan Marginean, Dan Dubina, Ioan Petran. (2016). Experimental testing and numerical analysis of 3D steel frame system under column loss. Engineering Structures, 113. 59-70. DOI:10.1016/j.engstruct. 2016.01.022 
Ou Zhao; Leroy Gardner; and Ben Young, (2016). Experimental Study of Ferritic Stainless Steel Tubular Beam-Column Members Subjected to Unequal End Moments. Journal of Structural Engineering. Vol. 142, Issue 11 https://doi.org/10.1061/(ASCE)ST.1943-541X.0001563

М. В. Гоголь, М. В. Котів, І. Д. Пелешко, Д. П. Сидорак Національний університет “Львівська політехніка", кафедра будівельного виробництва

\section{РЕГУЛЮВАННЯ НАПРУЖЕНО-ДЕФОРМОВАНОГО СТАНУ В СТИСНУТИХ ЕЛЕМЕНТАХ СТАЛЕВИХ КАРКАСІВ}

(С Гоголь М. В., Котів М. В., Пелешко І. Д., Сидорак Д. П., 2021

Розглянуто регулювання напружено-деформованого стану (НДС) в стиснутих елементах сталевих каркасів під повним експлуатаційним навантаженням. Запропоновано виконувати підсилення таких елементів 3 різними кінцевими ексцентриситетами прикладання навантаження раціональним регулюванням напружено-деформованого стану в елементах підсилення і підсилених стрижнях конструкції. Експериментально підтверджено, що запропонований спосіб регулювання НДС для рамних стійок дає змогу не тільки змінювати величини регулювального зусилля вздовж основного стержня, але і його знак. Несуча здатність стійок, підсилених з регулюванням НДС менша на 4 \% порівняно 3 монолітними стійками і більша на 18 \% порівняно з стійками підсиленими без регулювання.

Показано, що використання регулювання НДС для рамних стійок підвищує їх несучу здатність і зменшує деформативність та зварні деформації. Визначено мінімальну витрату сталі на підсилення рами за збільшення перерізів наявних елементів. Для практичної реалізації регулювання НДС у зайвих в'язях рами розроблено знімні напружувальні пристрої. Запропоновано технологію регулювання НДС і можливі конструктивні рішення знімних напружувальних пристроїв для введення згинальних моментів у зайві в'язі рамних систем. Числовим експериментом виявлено високу ефективність застосування запропонованих рішень для проектування реконструкції та підсилення розглянутої металевої рамної системи з великим ступенем статичної невизначеності. Вартість “в ділі” знижується вдвічі, а витрати металу на підсилення - в 3,3 раза. Виконане впровадження запропонованого способу регулювання НДС за підсилення рамних стійок підтвердило його ефективність.

Ключові слова: реконструкція, стійки, регулювання ПДВ, підсилення, напружено-деформований стан, несуча здатність, стійки 3 різними ексцентриситетами, експериментальні та числові дослідження, впровадження. 